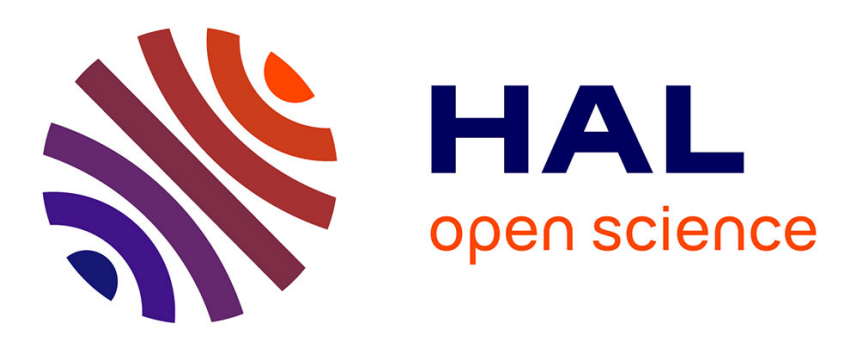

\title{
Influence of agricultural practices on arthropod communities in a vertisol (Martinique)
}

Gladys Loranger, Jean-François Ponge, Patrick Lavelle

\section{To cite this version:}

Gladys Loranger, Jean-François Ponge, Patrick Lavelle. Influence of agricultural practices on arthropod communities in a vertisol (Martinique). European Journal of Soil Biology, 1998, 34 (4), pp.157165. 10.1016/S1164-5563(00)86658-3 . hal-00505462

\section{HAL Id: hal-00505462 \\ https://hal.science/hal-00505462}

Submitted on 23 Jul 2010

HAL is a multi-disciplinary open access archive for the deposit and dissemination of scientific research documents, whether they are published or not. The documents may come from teaching and research institutions in France or abroad, or from public or private research centers.
L'archive ouverte pluridisciplinaire HAL, est destinée au dépôt et à la diffusion de documents scientifiques de niveau recherche, publiés ou non, émanant des établissements d'enseignement et de recherche français ou étrangers, des laboratoires publics ou privés. 


\section{INFLUENCE OF AGRICULTURAL PRACTICES ON ARTHROPOD COMMUNITIES IN A VERTISOL (MARTINIQUE)}

Gladys Loranger $^{(1) *}$, Jean François Ponge ${ }^{(2)}$, Eric Blanchart ${ }^{(3)}$ and Patrick Lavelle ${ }^{(1)}$

${ }^{(1)}$ Laboratoire d'Ecologie des Sols Tropicaux, IRD / Université Paris VI, 32 Avenue Henri Varagnat, F-93143 Bondy France.

(2) Muséum National d'Histoire Naturelle, Laboratoire d'Ecologie Générale, 4 Avenue du Petit Château, F-91800 Brunoy France.

(3) Laboratoire de Biologie et d'Organisation des Sols Tropicaux, IRD B.P. 8006, 97259 Fort de France, Martinique, French West Indies.

Short title : Agricultural practices and soil arthropods

\section{* Corresponding author}

Gladys Loranger, Laboratoire d'Ecologie des Sols Tropicaux, IRD, 32 Avenue Henri Varagnat, F-93143 Bondy France.

Fax number: +33.1.60.46.50.09.; E-mail: jean-francois.ponge@wanadoo.fr 


\begin{abstract}
The influence of human activities on soil arthropods of vertisols was assessed in several plots characterized by different land uses in the south-eastern part of Martinique (French West Indies). Abundance and diversity of soil invertebrate groups and collembolan species were measured in a 40-year-old secondary forest, a 15 -year-old fallow, a 4-year-old fallow, a 4-year-old pasture, a 15-year-old pasture and a 20-year-old market-garden. Agricultural practices modified abundance and species distribution of soil arthropods, compared to forest. Arthropod richness (number of taxa present) decreased from forest to market-garden, according to a gradient of intensification of agricultural use (pesticides, tillage, weed control). In the old pasture, the arthropod diversity was lower in spite of a high carbon content. Species richness of Collembola decreased together with plant diversity and water availability.
\end{abstract}

Keywords : Soil arthropods, Collembola, Agricultural practices, Biodiversity

Titre français : Influence des pratiques agricoles sur les communautés d'arthropodes dans un vertisol (Martinique)

\title{
Résumé
}

L'impact des activités humaines sur l'abondance et la diversité des arthropodes du sol est étudié dans un vertisol du sud-est de la Martinique. L'abondance et la diversité de l'ensemble des arthropodes et des peuplements de collemboles sont mesurées dans une forêt secondaire de 40 ans, une jachère de 15 ans, une jachère de 4 ans, un pâturage de 4 ans, un pâturage de 15 ans et un maraîchage de 20 ans. Les pratiques agricoles modifient l'abondance des peuplements d'invertébrés et la distribution des espèces. La richesse zoologique (nombre de groupes taxonomiques présents) diminue de la forêt au 
maraîchage, avec l'augmentation de la pression anthropique (diminution de la diversité végétale, ajout de pesticides, travail du sol). Dans le cas du pâturage âgé, on observe une faible diversité d'arthropodes malgré une teneur en carbone élevée. La richesse spécifique des collemboles diminue en même temps que la diversité végétale et la disponibilité hydrique.

Mots clés : Arthropodes du sol, Collemboles, Pratiques agricoles, Biodiversité.

\section{Introduction}

Soil functioning is affected by the abundance and the diversity of soil organisms. Decreases of diversity due to human activities may induce a degradation of soils and some changes in functional processes [22]. Species diversity and abundance of soil invertebrate communities are mainly determined by climate, quality and quantity of detritus inputs to the soil and by the structural stability of soil and litter habitats [4]. In agroecosystems, the amount and the quality of organic inputs decrease and tillage disturbs soil habitats. This often results in losses of soil fauna diversity [13] with the subsequent impairment of functions fulfilled by soil animals.

During the last decade, there was an intensification of agriculture in the south-eastern part of Martinique (French West Indies). The influence of land use on the physical structure and on the status of organic matter has been already studied in vertisols [17]. Theses soils are among the richest tropical soils. They are present under climates with contrasted seasons and they are characterized by a high clay (smectite) content. Their instability is due to the appearance of shrinkage cracks during dry periods followed by swelling during wet periods [24]. Under cropping, the soil organic matter content may decrease down to very low levels [3]. 
This study aimed to assess the impact of agricultural practices on soil invertebrates and in particular on collembolan communities in similar soils submitted to different land uses: a secondary forest, an old fallow, a recent fallow, a recent pasture, an old pasture and an old market-garden.

\section{Materials and methods}

\subsection{Site description}

The study was carried out near Sainte-Anne, in the south-eastern part of Martinique (French West Indies). This area receives on average an annual rainfall of $1400 \mathrm{~mm}$. The soil is a calco-magneso-sodic vertisol characterised by $: \mathrm{Ca} / \mathrm{Mg}=1.5 \%$ and $\mathrm{Na}^{+} / \mathrm{Cation}$ Exchange Capacity $=16 \%$.

Six plots were selected: a 15-year-old fallow, a 4-year-old fallow, a 4-year-old pasture, a 15-year-old pasture, an 20-year-old market-garden and a 40-year-old secondary forest. The first five plots were located at the SECI experimental station (Station d'Essais en Cultures Irriguées - Conseil Général de la Martinique). They had been previously cropped to sugarcane for several decades. The secondary forest site was located $5 \mathrm{~km}$ further on similar soil, at Pointe Cailloux. It was previously an old sugarcane plantation, abandoned 40 years ago. The vegetation is xerophilous. The old fallow had been planted to Cynodon dactylon (Bermuda grass) in 1980. This plot was covered thereafter by a natural xero-heliophilous vegetation, at the advanced herbaceous stage. The recent fallow and the recent pasture (4-year-old) had the same history. After fifteen years of market-gardening, they were turned to pasture with Digitaria decumbens (pangola grass) in 1991, then they were grazed by sheep and regularly irrigated and fertilised. However, contrary to the pasture, the recent fallow had been unsuccessfully planted and natural vegetation covered the plot instead. The old pasture had been 
established more than fifteen years before the study. The old market-garden had been cultivated in rotation farming for the last twenty years. Main characteristics and carbon content of the topsoil in the different plots are given in table I.

\subsection{Soil fauna}

Soil arthropods were sampled along a transect line. Ten regularly spaced cores, $10 \times$ $10 \mathrm{~cm}$ in cross-section and $3 \mathrm{~cm}$ depth, were taken in each plot. Previous sampling showed that $75 \%$ soil arthropods inhabited the top $3 \mathrm{~cm}$. Soil invertebrates were extracted for 48 hours in Berlese funnels at $313 \mathrm{~K}\left(40^{\circ} \mathrm{C}\right)$. Preliminary assays allowed to determine the duration of extraction. Most arthropods fell out within 48 hours [23]. Sampling and extraction were achieved in February 1995, during the dry season. Arthropods were counted under a dissecting microscope and they were classified into 22 taxa (19 orders and 3 larval groups). Collembola were sorted out and when possible they were identified at the species level using Betsch \& Lasebikan [7], Christiansen \& Bellinger [9], Denis [11], Gisin [14], Massoud and Thibaud [25, 26], and Thibaud and Massoud [30, 31]. The size of each individual was measured. Two size classes were defined: class $1(<1.5 \mathrm{~mm})$ comprising mostly endogeic species, with short appendages (antennae, legs and furcula), and class $2(\geq 1.5 \mathrm{~mm})$, comprising mostly epigeic species with long appendages.

In each plot, the zoological richness was assessed by counting the number of taxa present. Collembolan species richness was assessed similarly. The Sorensen's index of similarity, I [15], was used to compare collembolan communities between disturbed and forested plots:

$I=2 c /(a+b)$, where $a$ is the number of species in the forest; $b$ the number of species in the disturbed plot; and $\mathrm{c}$ the number of species in common. 


\subsection{Statistical analysis}

Correspondence analysis (CA), a multivariate method based on chi-square distance [16] was performed on arthropod groups and collembola species, using STAT-ITCFTM. One of the peculiarities of $\mathrm{CA}$ is the simultaneous projection of samples and variables on the same graph, variable-points located within a group of sample-points being typical for this group. Densities for each animal group were reweighted (S.D. = 1) and focused to a mean of 20 as in a previous study [23]. In order to help interpreting the factorial axes, carbon content (C) and treatments (F: forest OF: old fallow, RF: recent fallow, RP: recent pasture, OP: old pasture, MG: market-garden) were used as additional variables, i.e. they were plotted even though not originally included in the matrix to be analysed. Mann-Whitney non-parametric test [28] was used to compare the densities of main arthropod groups among different land uses. Each group was analysed separately by comparing pairs of plots in order to find homogeneous groups among plots. The same test was used to compare the abundance of the two size classes of Collembola in the different plots.

\section{Results}

\subsection{Total fauna}

\subsubsection{Densities}

The total number of arthropods decreased in the order: recent fallow $>$ forest $>$ old pasture $>$ recent pasture $>$ old fallow $>$ market-garden (table II). The recent fallow had the highest density of Acari (42,170 individuals.m ${ }^{-2}$ as compared to 30,410 individuals. $\mathrm{m}^{-2}$ in the forest), Collembola (7,260 individuals. $\mathrm{m}^{-2}$ as compared to 5,120 individuals. $\mathrm{m}^{-2}$ in the forest), Formicoidea, Isopoda, Diplopoda and Dermaptera. The 
secondary forest site with 38,000 individuals. $\mathrm{m}^{-2}$ had the second highest total arthropod density. Greatest abundance of Pseudoscorpionida, Pauropoda, Diplura and Isoptera (termites) was characteristic of the forested plot. The forest site exhibited the highest densities of Coleoptera (adult and larvae), Diplopoda (in common with the recent fallow), Symphyla, Protura, Chilopoda, Heteroptera, Araneide and Thysanoptera (in common with the old fallow). The old pasture $\left(31,460\right.$ arthropods.m $\left.{ }^{-2}\right)$ had high densities of Acari, Collembola and Formicoidea. The recent pasture $(12,890$ arthropods.m ${ }^{-2}$ ) had high density of Acari, Collembola and Formicoidea and had the highest density of Diptera larvae. The old fallow (10,090 arthropods.m $\left.{ }^{-2}\right)$ was characterized by the lowest density of Collembola. The market-garden site was the poorest in Acari, Formicoidea, Dermaptera and Coleoptera larvae but exhibited the highest density of Homoptera. Mann-Whitney's test showed significant differences among plots for Acari, Collembola, Diplopoda, Chilopoda, Isopoda, Formicoidea, Coleoptera, Homoptera, Coleoptera larvae and Diptera larvae (table III). The recent fallow was the most similar to the forest for most arthropod groups, except for Coleoptera, Chilopoda, Isopoda and Formicoidea.

CA was performed on all samples and animal groups (figure 1). Axes 1 to 4 accounted for 27.5, 12.8, 9.8 and $6.6 \%$ of total variance, respectively. Axis 1 opposed the secondary forest with the highest carbon content (36\%), and the highest zoological richness and abundance to the other plots. This axis may correspond to a "land use gradient", with the market-garden most opposed to the forest, and the recent fallow nearest the forest. Axis 2 opposed the recent fallow, with the highest arthropod density, to all other plots, the market-garden and the old fallow being most opposed. This axis may correspond to a "density gradient". CA did not clearly separate the plots with lower 
densities of soil arthropods. The poorest sites (market-garden and old fallow) were placed on the negatives sides of both axes 1 and 2 .

\subsubsection{Zoological richness}

Twenty-two taxonomical groups were present in total. The zoological richness decreased in the following order: forest (20 groups of arthropods) $>$ recent fallow $=$ recent pasture $(14$ groups $)>$ old pasture $=$ old fallow $(12$ groups $)>$ market-garden $(8$ groups), which was reflected in the ordination of land uses by axis 1 of CA (figure 1). Isopoda and Dermaptera were unexpectedly completely absent in the forest soil. Figure 2 shows gains and losses in arthropod groups when agricultural plots were compared to the forest. The market-garden lost most arthropod groups (14).

\subsection{Collembola}

\subsubsection{Species occurrence}

Twenty-seven species of Collembola were found in the studied plots (table IV). Some collembolan species were only found in one plot, e.g. Acherontiella sp.1, cf. Sinella sp., Stenognatriopes sp., Xenylla sp.3 in the forest, while others were ubiquitous like Lepidocyrtus sp.1 and Seira sp., which were found in all treatments. Each plot exhibited a particular species composition.

CA was performed on collembolan species (figure 3). Axes 1 to 4 accounted for 19.4, $11.5,9.7$ and $8.5 \%$ of the total variance, respectively. Axis 1 opposed the forest to the old pasture, with profound changes in the species composition. Axis 2 opposed the recent fallow to both the old pasture and the forest, with Acherontiella sp. 2 composing almost the whole collembolan fauna in the recent fallow. The collembolan communities of the old fallow, of the market-garden and of the recent pasture were not differentiated 
from other plots by CA, the old fallow being placed in an intermediary position between the recent fallow and the forest.

\subsubsection{Species richness}

Species richness decreased in the order: forest $(20$ species $)>$ recent fallow (15) $>$ old pasture $(13)>$ recent pasture $(11)>$ market-garden (7) $>$ old fallow (2). Figure 4 shows gains and losses of collembolan species in the disturbed plots compared to the forested plot. Sorensen's indices (table IV) showed that the recent fallow was the most similar to the forest and the old fallow the most dissimilar.

\subsubsection{Size classes}

Species of collembola were classified in two groups: small endogeic species and large epigeic species. Relative contributions of these ecological categories to the whole collembolan community were compared among the sites (table $V$ ). There was a significant influence of land use on the balance between both two size classes. In the recent pasture and in the market-garden, there were significantly more epigeic (class 2) than endogeic Collembola (class 1). On the contrary the forest had less epigeic than endogeic animals.

\section{Discussion}

Forty years after the abandonment of sugarcane plantation, the topsoil of the secondary forest has a high carbon content. The recolonization by woody vegetation of abandoned agricultural plots allows the restoration of a high carbon content [8]. This secondary forest harbours an abundant and diverse arthropod fauna, too. However, the 
arthropod density is still low compared to other secondary dryland forests under similar climate $[1,2]$.

The recent fallow and the recent pasture had a rather similar zoological richness, although lower than the forest. The high abundance and zoological richness of arthropods in these plots were probably caused by irrigation and fertilisation, the absence of ploughing and a lower grazing pressure compared to plots used for intensive pasture [19]. Some arthropod groups present in the forest were absent in these plots, probably due to a lower litter quality and quantity.

In the old fallow the absence of a dense cover for soil arthropods (grasses are cut each year) and the lack of water (absence of irrigation) may explain the low arthropod density and the low zoological richness.

In the old pasture, the dominance of Digitaria decumbens may explain the low zoological richness of soil arthropod fauna. However, in this plot, the carbon content is as high as $30 \%$ (36\% in the forest), which could indicate that the diversity of food resources is at least as important as its amount for the maintenance of a diverse soil fauna.

Soil arthropod communities were markedly depleted in the market-garden system. Intense agricultural practices are known to reduce arthropod diversity and density [10, 27, 29]. After a long time of intensive cropping, several factors may explain the observed decrease in invertebrate density and zoological richness. Intense use of pesticides, intense cropping and heavy tillage cause soil compaction, and destroy most soil and litter microhabitats [13].

In spite of relatively dry conditions due to a high water uptake, rainfall interception by leaves and lack of irrigation, the forest site harbours an abundant and diverse collembolan community. The presence of leaf litter, which creates suitable microclimate 
conditions at the soil surface, retains moisture and offers diverse food resources may explain this figure. The two endogeic earthworm species which are present on this plot (Polypheretima elongata and Pontoscolex sp.) probably create favourable conditions for soil-dwelling arthropods, too.

In the recent fallow (following 15 years of intense market-gardening) the density of collembola was greater than in the forest, but this is due to few species that dominate the collembolan community. Despite differences in the Collembolan species composition, some forest species (Acherontiella sp.2, Dicyrtomina cf. opalina, Isotomodes sp., Lepidocyrtus sp.3 Pseudachorutes sp.) appear in the recent fallow, giving clear indication of a recolonization by the forest collembolan community.

In the old pasture, the presence of a dense continuous grass layer, protecting the soil against erosion, irrigation and giving it a high carbon content, can explain the maintainance of some collembolan richness. This plot exhibited the highest abundance of large-sized species (table $V$ ), probably due to a higher amount of large pores created by the earthworm $P$. elongata. Populations of this endogeic worm can usually reach a high biomass on these plots [6]. A strong influence of the density of earthworms on the size and density of Collembola has already been demonstrated in this pasture by Loranger et al. [23].

In the tilled vertisol of the market-garden, endogeic small collembolan species decreased in the topsoil contrary to more motile and larger epigeic species which probably are better able to recolonize the plot each year [12, 32]. Given that sampling was not done below $3 \mathrm{~cm}$ depth, deeper-living endogeic collembolan species were possibly underestimated.

The old fallow had the lowest density of Collembola, probably due to the absence of litter and to the lack of water (no irrigation). As a matter of fact, water availability is 
important for invertebrates, especially those which respire through their integument such as Collembola [5, 20, 33].

During the dry period, a vertisol is unfavourable to the development of soil animal populations and in particular to Collembola, due to physiological dryness (high content in smectites). The soil fauna could sink along shrinkage cracks (endogeic species) or colonize contiguous irrigated plots (epigeic species). In fact, in the old fallow, small shrinkage cracks were observed and we obviously reported a low arthropod and collembolan density, too. In the other cultivated plots, irrigation prevents the development of shrinkage cracks, as litter does in the forest.

\section{Conclusion}

In tropical vertisols changes in arthropod communities indicate a decline in soil quality following agricultural use. However, the presence of diverse vegetation, irrigation and fertilisation can partly maintain zoological richness. A great part of the soil arthropod community has been recovered successfully after the abandonment of agriculture, through the restoration of a litter layer (secondary forest). Litter protects the soil against erosion, offers microhabitats and food to litter-dwelling groups, and prevents vertisols to shrink during dry periods. In disturbed plots, plant diversity, irrigation, fertilisation and low grazing pressure allow the maintenance of soil fauna.

\section{Acknowledgements}

Thanks are due to Rachel MORTON for revision of the English language. This study was partly funded by the French Ministry of Environment (SOFT programme). We are grateful to the Conseil Général de la Martinique for authorising sampling in the SECI 
experimental station. We also greatly acknowledge field assistance from the ORSTOM BOST laboratory. 


\section{References}

[1] Adis J., On the abundance and density of terrestrial arthropods in Central Amazonian dryland forests, J.Trop. Ecol. 4, (1988) 19-24.

[2] Adis J., De Morais J.W., Ribeiro E.F., Vertical distribution and abundance of arthropods in the soil of a neotropical secondary forest during the dry season. Trop. Ecol. 28, (1987) 174-181.

[3] Albrecht A. Brossard M., Chotte J.L., Feller C., Les stocks organiques des principaux sols cultivés de la Martinique (Petites Antilles), Cahiers ORSTOM Pédologie, 1, (1992) 23-26.

[4] Anderson J.M., The role of soil fauna in agricultural systems, in: Wilsons J.R. (Ed.) Advances in Nitrogen cycling in agricultural ecosystems, 1988, pp. 89-112.

[5] Athias F., Données complémentaires sur l'abondance et la distribution des microarthropodes de la savane de Lamto (Côte d'Ivoire), Bull. Mus. Natn. Hist. Nat. $308,(1975) 1-28$.

[6] Barois I., Cadet P., Albrecht A., Lavelle P., Système de culture et faune des sols. Quelques données. in: Feller C. (Ed.) Fertilité des sols dans les agricultures paysannes caribéennes. Effet des restitutions organiques ORSTOM - Martinique, 1988, pp. 85-96.

[7] Betcsh J.M., Lasebikan B.A., Collemboles du Nigéria, I. Stenognathriopes, un nouveau genre de Symphypléones, Bull. Soc. Ent. France 84, (1979) 165-170.

[8] Brown S., Lugo A.E., Tropical secondary forest. J. Trop. Ecol. 6, (1990) 1-32.

[9] Christiansen K.A., Bellinger P.F. The Collembola of North America, north of the Rio Grande, a taxonomic analysis, 1980-81, Grinnel College, Grinnell, Iowa.

[10] Dangerfield J.M, Abundance, biomass and diversity of soil macrofauna in savanna woodland and associated managed habitats. Pedobiologia 34, (1990) 141-150. 
[11] Denis J.R., Contributo alla conoscenza del "Microgenton" di Costa Rica. Collemboles de Costa Rica avec une contribution au species de l'ordre. R. Laboratorio di Entomologia agraria Portici, 1962, pp. 69-320.

[12] Gers C., Incidence de la simplification du sol sur la microfaune édaphique hivernale: données préliminaires, Rev. Ecol. Biol. Sol, 19, (1982) 593-604.

[13] Giller K.E., Beare M.H., Lavelle P. Izac A.-M.N., Swift M.J., Agricultural intensification, soil biodiversity and agrosystem function. Appl. Soil Ecol. 6, (1997) 316.

[14] Gisin H., Collembolen fauna europas. Muséum d'Histoire Naturelle, Genève, Suisse, 1960.

[15] Gounot M., Méthodes d'étude quantitative de la végétation. Masson, Paris, France, 1969.

[16] Greenacre M.J., Theory and applications of correspondence analysis. Academic press, London, UK, 1984.

[17] Hartmann C., Blanchart E., Albrecht A., Bonneton A., Parfait F., Mahieu M., Gaullier C., Ndandou J.F., Nouvelles techniques de préparation des vertisols en culture maraîchère à la Martinique : incidences pédologiques et agronomiques. Agriculture et développement 18, (1998) 81-89.

[19] Hutchinson K.L., King K.L., The effects of sheep stocking level on invertebrate abundance, biomass and energy utilization in a temperate, sown grassland. J Appl Ecol, 17, (1960) 369-387.

[20] Joosse E.N.G., The formation and biological significance of aggregations in the distribution of Collembola. Neth. J. Zool. 20, (1970) 299-314. 
[21] Kulesza V., Evolution de la structure des vertisols de la Martinique en fonction du système de culture, Mémoire de fin d'année, I.S.T.O.M, 1994.

[22] Lawton J.H., Brown V.K., Redundancy in ecosystems. in Schulze E.D., Mooney H.A. (Eds.) Biodiversity and ecosystem function. Springer, New York, 1993.

[23] Loranger G., Ponge J.F., Blanchart E., Lavelle P., Impact of earthworms on the diversity of microarthropods in a vertisol (Martinique), Biol. Fertil. Soils 27, (1997) 2126.

[24] Lozet J., Mathieu C., Dictionnaire de science du sol, Technique et Documentation, Lavoisier, Paris, 1990.

[25] Massoud Z., Thibaud J.M., Les collemboles des petites Antilles. II-Neanuridae. Rev. Ecol. Biol. Sol 17, (1980) 591-605.

[26] Massoud Z., Thibaud J.M., Les collemboles des petites Antilles. IV-Neanuridae (suite et fin). Rev. Ecol. Biol. Sol 24, (1987) 91-98.

[27] Reddy M.V., Reddy V.R., Yule D.F., Cogle A.L., George P.J., Decomposition of straw in relation to tillage, moisture, and arthropod abundance in a semi-arid tropical Alfisol, Biol. Fertil. Soils, 17 (1994) 45-50.

[28] Sokal R.R., Rohlf F.J., Biometry. The principles and practice of statistics in biological research, Freeman W.H. and Company, New York, 1995.

[29] Stork N.E., Eggleton P., Invertebrates as determinants and indicators of soil quality. Am. J. Altern. Agric. 7, (1992) 38-47.

[30] Thibaud J.M., Massoud Z. Les collemboles des petites Antilles. I-Hypogastruridae et Onychiuridae. Rev. Ecol. Biol. Sol 26, (1979) 547-567.

[31] Thibaud J.M., Massoud Z., Les collemboles des petites Antilles. III-Neanuridae (Pseudochoriturinae). Rev. Ecol. Biol. Sol 20, (1983) 111-129. 
[32] Ushiwata C.T., Sautter K.D., Kobiyama M., Influence of compaction of a forest soil on the soil fauna in a subtropical region. I. Oribatei Acari, Cryptostigmata and Collembola Insecta, Revta. Bras. Zool. 12, . (1995) 905-913.

[33] Verhoef H.A., Van Selm A.J., Distribution and population dynamics of Collembola in relation to soil moisture. Hol. Ecol. 6, (1983) 387-394. 


\section{LEGENDS OF FIGURES}

Figure 1: Correspondence analysis (CA) on all Berlese-extracted arthropod groups. Projection of samples and taxa in the plane of axes 1 and 2.

$\mathrm{OP}=$ old pasture, $\mathrm{RP}=$ recent pasture, $\mathrm{OF}=$ old fallow, $\mathrm{RF}=$ recent fallow, $\mathrm{MG}=$ market-garden, $\mathrm{F}=$ secondary forest, $\mathrm{C}=$ carbon content.

Figure 2: Changes of the zoological richness in the different plots, by comparison with the forest.

Figure 3: Correspondence analysis (CA) on Collembolan species. Projection in the plane of axes 1 and 2. Elsewhere as for Fig. 1.

Figure 4: Changes of the Collembolan species richness in the different plots, by comparison with the forest. Sorensen's indices (I) are indicated for each plot. 
Table I Characteristics of the studied plots

\begin{tabular}{|c|c|c|c|c|c|c|}
\hline & Old Pasture & Recent Pasture & Old Fallow & Recent Fallow & Market-garden & Forest \\
\hline Age & $>15$-year-old & 4-year-old & 15-year-old & 4-year-old & 20-year-old & 40-year-old \\
\hline Culture & $\begin{array}{c}\text { Digitaria decumbens } \\
\text { (Pangola grass). It formed a } \\
\text { dense continuous herb } \\
\text { layer. }\end{array}$ & D. decumbens & $\begin{array}{c}\text { Cynodon dactylon } \\
\text { (Bermuda grass) } \\
\text { and natural } \\
\text { vegetation; } \\
\text { cut each year }\end{array}$ & $\begin{array}{l}\text { D. decumbens } \\
\text { and natural } \\
\text { grassland } \\
\text { vegetation }\end{array}$ & melon & $\begin{array}{c}\text { Natural } \\
\text { xerophilous } \\
\text { vegetation }\end{array}$ \\
\hline Grazing & Sheep - bovines & sheep & no & sheep & no & no \\
\hline Fertilisation & yes & yes & no & yes & yes & no \\
\hline \begin{tabular}{|l|} 
Irrigation \\
\end{tabular} & yes & yes & no & yes & yes & no \\
\hline Pesticides & no & no & no & no & yes & no \\
\hline \begin{tabular}{|l|} 
Dominant \\
earthworm \\
species
\end{tabular} & Polypheretima elongata & $\begin{array}{c}\text { P. elongata } \text { and } 2 \\
\text { unidentified species }\end{array}$ & $\begin{array}{l}\text { P. elongata and } 2 \\
\text { unidentified } \\
\text { species }\end{array}$ & $\begin{array}{c}\text { P. elongata } \\
\text { and } \\
2 \text { unidentified } \\
\text { species }\end{array}$ & $\begin{array}{l}2 \text { unidentified } \\
\text { species }\end{array}$ & $\begin{array}{l}\text { P. elongata } \\
\text { Pontoscolex } \\
\text { sp. }\end{array}$ \\
\hline Topsoil [21] & $\begin{array}{c}(25 \mathrm{~cm}) \\
\text { Brown clay horizon } \\
(>60 \% \text { smectites }) \\
\text { Coarse polyhedral structure }\end{array}$ & $\begin{array}{l}\text { ( }(35 \mathrm{~cm}) \\
\text { Brown clay horizon. } \\
\text { Polyhedral structure }\end{array}$ & & $\begin{array}{l}(10 \mathrm{~cm}) \\
\text { Compact. } \\
\text { Polyhedral } \\
\text { structure }\end{array}$ & $\begin{array}{c}(10 \mathrm{~cm}) \\
\text { Grey brown and } \\
\text { clayish. } \\
\text { Polyhedral } \\
\text { structure }\end{array}$ & $\begin{array}{l}\text { Brown. } \\
\text { Granular } \\
\text { structure. }\end{array}$ \\
\hline $\begin{array}{l}\text { Carbon content } \\
0-10 \mathrm{~cm} \\
(\mathrm{mg} \mathrm{C} / \mathrm{g} \text { soil })\end{array}$ & 30 & 18 & 20 & 18 & 13 & 36 \\
\hline
\end{tabular}


Table II Arthropod densities (ind. $\mathrm{m}^{-2}$ ) in the different plots (mean followed by S.E.)

\begin{tabular}{|c|c|c|c|c|c|c|}
\hline & Forest & Old Pasture & Recent Pasture & Old Fallow & Recent Fallow & $\begin{array}{l}\text { Market- } \\
\text { garden }\end{array}$ \\
\hline Acari & $30410(2870)$ & 22480 (3999) & $7850(1838)$ & $9240(1554)$ & $42170(5331)$ & $\overline{6540(1390)}$ \\
\hline Araneidae & $40(32)$ & $10(9)$ & $30(212)$ & $20(13)$ & $30(16)$ & 0 \\
\hline Pseudoscorpionida & $130(51)$ & 0 & 0 & 0 & 0 & 0 \\
\hline Diplopoda & $300(63)$ & 0 & $130(44)$ & $10(9)$ & $300(82)$ & 0 \\
\hline Chilopoda & $110(28)$ & 0 & $20(13)$ & 0 & 0 & 0 \\
\hline Symphyla & $170(25)$ & 0 & 0 & 0 & $10(9)$ & 0 \\
\hline Pauropoda & $240(35)$ & 0 & 0 & 0 & 0 & 0 \\
\hline Isopoda & 0 & $70(35)$ & $790(164)$ & $50(22)$ & $2170(829)$ & $480(285)$ \\
\hline Collembola & $5120(851)$ & $4160(1894)$ & $2160328)$ & $70(26)$ & 7260 (1990) & $1170(373)$ \\
\hline Protura & $120(32)$ & 0 & $100(41)$ & 0 & 0 & 0 \\
\hline Diplura & $140(9)$ & 0 & 0 & 0 & 0 & 0 \\
\hline Thysanoptera & $30(22)$ & $20(13)$ & $10(9)$ & $30(22)$ & $10(9)$ & 0 \\
\hline Dermaptera & 0 & $20(13)$ & 0 & 0 & $100(28)$ & $10(9)$ \\
\hline Homoptera & $390(148)$ & $120(35)$ & 0 & $70(26)$ & $50(32)$ & $490(262)$ \\
\hline Heteroptera & $40(22)$ & 0 & $10(9)$ & 0 & 0 & 0 \\
\hline Formicoidea & $220(117)$ & $4510(2517)$ & $1480(822)$ & $430(104)$ & $5890(2283)$ & $30(28)$ \\
\hline Isoptera & $10(9)$ & 0 & 0 & 0 & 0 & 0 \\
\hline Coleoptera & 410 (149) & 0 & $20(13)$ & 0 & $30(16)$ & 0 \\
\hline Coleoptera larvae & $550(136)$ & $30(22)$ & $40(16)$ & $110(32)$ & $160(32)$ & $10(9)$ \\
\hline Diptera larvae & $120(95)$ & $20(13)$ & $250(117)$ & $10(9)$ & $20(13)$ & 0 \\
\hline Other insect larvae & $20(19)$ & $20(13)$ & 0 & $50(35)$ & 0 & 0 \\
\hline TOTAL & 38570 (3772) & $31460(8563)$ & $12890(3630)$ & $10090(1859)$ & 58200 (10669) & 8730 (2359) \\
\hline
\end{tabular}


Table III Comparison of the different plots for key arthropod groups (ManWitney's test). * : $\mathrm{p}<0.05 ; \mathrm{a}, \mathrm{b}, \mathrm{c}, \mathrm{d}$ : decreasing order of means homogeneous groups.

\begin{tabular}{lccccccc}
\hline & $\mathbf{p}$ & Forest & $\begin{array}{c}\text { Old } \\
\text { Pasture }\end{array}$ & $\begin{array}{c}\text { Recent } \\
\text { Pasture }\end{array}$ & $\begin{array}{c}\text { Old } \\
\text { Fallow }\end{array}$ & $\begin{array}{c}\text { Recent } \\
\text { Fallow }\end{array}$ & $\begin{array}{c}\text { Market- } \\
\text { garden }\end{array}$ \\
\hline Acari & $*$ & $\mathrm{ab}$ & $\mathrm{b}$ & $\mathrm{c}$ & $\mathrm{c}$ & $\mathrm{a}$ & $\mathrm{c}$ \\
Collembola & $*$ & $\mathrm{a}$ & $\mathrm{ab}$ & $\mathrm{b}$ & $\mathrm{c}$ & $\mathrm{a}$ & $\mathrm{b}$ \\
Diplopoda & $*$ & $\mathrm{a}$ & $\mathrm{b}$ & $\mathrm{a}$ & $\mathrm{b}$ & $\mathrm{a}$ & $\mathrm{b}$ \\
Chilopoda & $*$ & $\mathrm{a}$ & $\mathrm{b}$ & $\mathrm{b}$ & $\mathrm{b}$ & $\mathrm{b}$ & $\mathrm{b}$ \\
Isopoda & $*$ & $\mathrm{c}$ & $\mathrm{bc}$ & $\mathrm{a}$ & $\mathrm{c}$ & $\mathrm{a}$ & $\mathrm{ab}$ \\
Formicoidea & $*$ & $\mathrm{c}$ & $\mathrm{ab}$ & $\mathrm{b}$ & $\mathrm{b}$ & $\mathrm{a}$ & $\mathrm{c}$ \\
Coleoptera & $*$ & $\mathrm{a}$ & $\mathrm{b}$ & $\mathrm{b}$ & $\mathrm{b}$ & $\mathrm{b}$ & $\mathrm{b}$ \\
Homoptera & $*$ & $\mathrm{a}$ & $\mathrm{a}$ & $\mathrm{b}$ & $\mathrm{ab}$ & $\mathrm{ab}$ & $\mathrm{a}$ \\
Coleoptera larvae & $*$ & $\mathrm{a}$ & $\mathrm{cd}$ & $\mathrm{cd}$ & $\mathrm{bc}$ & $\mathrm{ab}$ & $\mathrm{d}$ \\
Diptera larvae & $*$ & $\mathrm{ab}$ & $\mathrm{ab}$ & $\mathrm{a}$ & $\mathrm{b}$ & $\mathrm{ab}$ & $\mathrm{b}$ \\
\hline
\end{tabular}


Table IV.- Collembolan species (ind. $\mathrm{m}^{-2}$ ) in the different plots : means followed by S.E. and ecological groups $(*)$ : epigeic species; $\left({ }^{*}\right)$ : endogeic species. Rs : Specific richness. I : Sorensen's index between disturbed plots and the forested plot.

\begin{tabular}{|c|c|c|c|c|c|c|}
\hline & Forest & $\begin{array}{c}\text { Old } \\
\text { Pasture }\end{array}$ & $\begin{array}{l}\text { Recent } \\
\text { Pasture }\end{array}$ & $\begin{array}{c}\text { Old } \\
\text { Fallow }\end{array}$ & $\begin{array}{l}\text { Recent } \\
\text { Fallow }\end{array}$ & $\begin{array}{c}\text { Market- } \\
\text { garden }\end{array}$ \\
\hline Acherontiella sp. $1(* *)$ & $20(19)$ & 0 & 0 & 0 & 0 & 0 \\
\hline Acherontiella sp. $2(* *)$ & $50(35)$ & 0 & 0 & 0 & $4370(1654)$ & 0 \\
\hline Arlesia albipes $(*)$ & 0 & 0 & $10(9)$ & 0 & 0 & 0 \\
\hline Brachystomella sp. $(* *)$ & 0 & $130(89)$ & $30(22)$ & 0 & $50(32)$ & 0 \\
\hline cf. Sinella sp. $(* *)$ & $120(60)$ & 0 & 0 & 0 & 0 & 0 \\
\hline Crypopygus cf. separatus & $280(101)$ & $1890(1287)$ & $960(272)$ & 0 & $1400(411)$ & 870 (309) \\
\hline Cryptopygus sp. 1 (**) & $10(9)$ & $220(76)$ & 0 & 0 & 0 & $20(19)$ \\
\hline Cryptopygus sp. $2(* *)$ & $90(41)$ & 0 & 0 & 0 & 0 & 0 \\
\hline Cyphoderus cf. similis (*) & $230(133)$ & $70(35)$ & $50(35)$ & 0 & $120(44)$ & 0 \\
\hline Dicyrtomina cf. opalina & $30(16)$ & 0 & 0 & 0 & $20(13)$ & 0 \\
\hline Folsomides americanus & $60(32)$ & $150(108)$ & $410(152)$ & 0 & $490(247)$ & 0 \\
\hline Heteromurus sp. $(*)$ & 0 & 0 & 0 & 0 & $20(19)$ & $10(9)$ \\
\hline Isomtomiella minor $(* *)$ & $10(9)$ & $220(76)$ & $120(76)$ & 0 & 0 & 0 \\
\hline Isotomodes sp. $(* *)$ & $330(130)$ & 0 & 0 & 0 & $130(79)$ & 0 \\
\hline Lepidocyrtus sp. 1 (*) & $10(9)$ & $410(142)$ & $210(57)$ & $10(9)$ & $240(120)$ & $140(41)$ \\
\hline Lepidocyrtus sp. $2(*)$ & 0 & 0 & $10(9)$ & 0 & 0 & 0 \\
\hline Lepidocyrtus sp. 3 (*) & $460(120)$ & 0 & 0 & 0 & $40(41)$ & 0 \\
\hline Megalothorax minimus & 0 & 0 & 0 & 0 & $10(9)$ & 0 \\
\hline Pseudachorutes sp. (**) & $450(142)$ & 0 & 0 & 0 & $120(73)$ & 0 \\
\hline Pseudosinelle sp. $(*)$ & $50(28)$ & $150(57)$ & $320(123)$ & 0 & $160(60)$ & $110(35)$ \\
\hline Salina banksi $(*)$ & 0 & $50(28)$ & 0 & 0 & $70(41)$ & 0 \\
\hline Seira bipunctata $(*)$ & 0 & $200(79)$ & 0 & 0 & 0 & 0 \\
\hline Seira sp. $(*)$ & $30(22)$ & $370(168)$ & $30(16)$ & $60(22)$ & $20(19)$ & $10(9)$ \\
\hline Stenognatriopes sp. $(* *)$ & $40(16)$ & 0 & 0 & 0 & 0 & 0 \\
\hline Xenylla sp. $1(* *)$ & $2690(553)$ & $250(209)$ & $10(9)$ & 0 & 0 & $10(9)$ \\
\hline Xenylla sp. $2(* *)$ & $90(70)$ & $50(32)$ & 0 & 0 & 0 & 0 \\
\hline Xenylla sp. $3(* *)$ & $70(35)$ & 0 & 0 & 0 & 0 & 0 \\
\hline Rs & 20 & 13 & 11 & 2 & 15 & 7 \\
\hline I & 1 & 0.606 & 0.516 & 0.182 & 0.629 & 0.44 \\
\hline
\end{tabular}


Table V Abundance of Collembola (ind. $\mathrm{m}^{-2}$ ) by size class in the different plots. ManWitney's test : $(*): \mathrm{p}=0.05,(\mathrm{~ns})$ non-significant.

\begin{tabular}{lccc}
\hline & & $\begin{array}{c}\text { Class 1 }(<1.5 \mathrm{~mm}) \\
\text { endogeic species }\end{array}$ & $\begin{array}{c}\text { Class 2 }(\geq 1.5 \mathrm{~mm}) \\
\text { epigeic species }\end{array}$ \\
\hline Forest & $*$ & 4060 & 1060 \\
Old pasture & $\mathrm{ns}$ & 1020 & 3140 \\
Recent pasture & $*$ & 570 & 1590 \\
Old fallow & $\mathrm{ns}$ & 0 & 70 \\
Recent fallow & $\mathrm{ns}$ & 5190 & 2070 \\
Market-garden & $*$ & 30 & 1140 \\
\hline
\end{tabular}




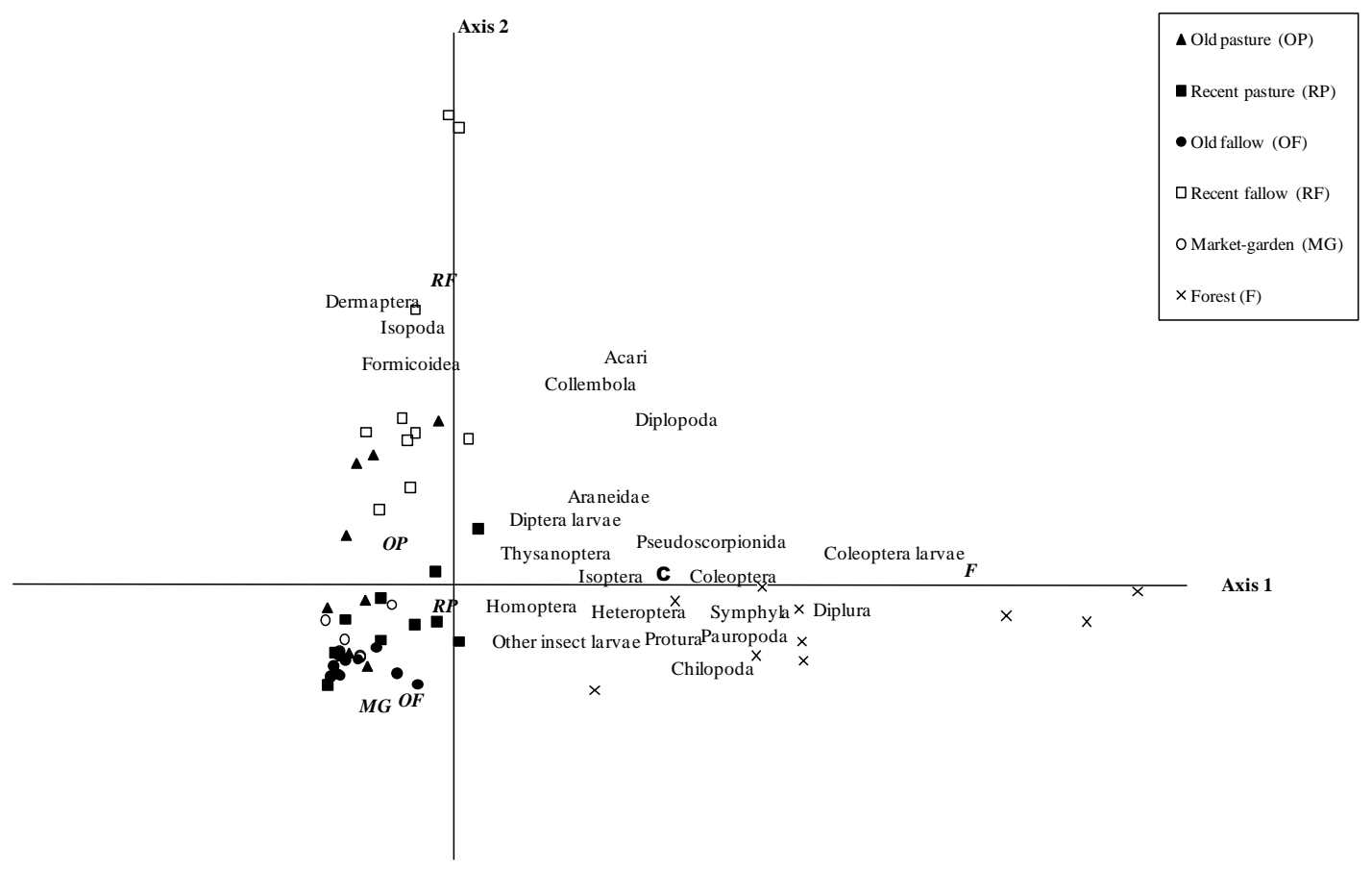

Fig. 1 


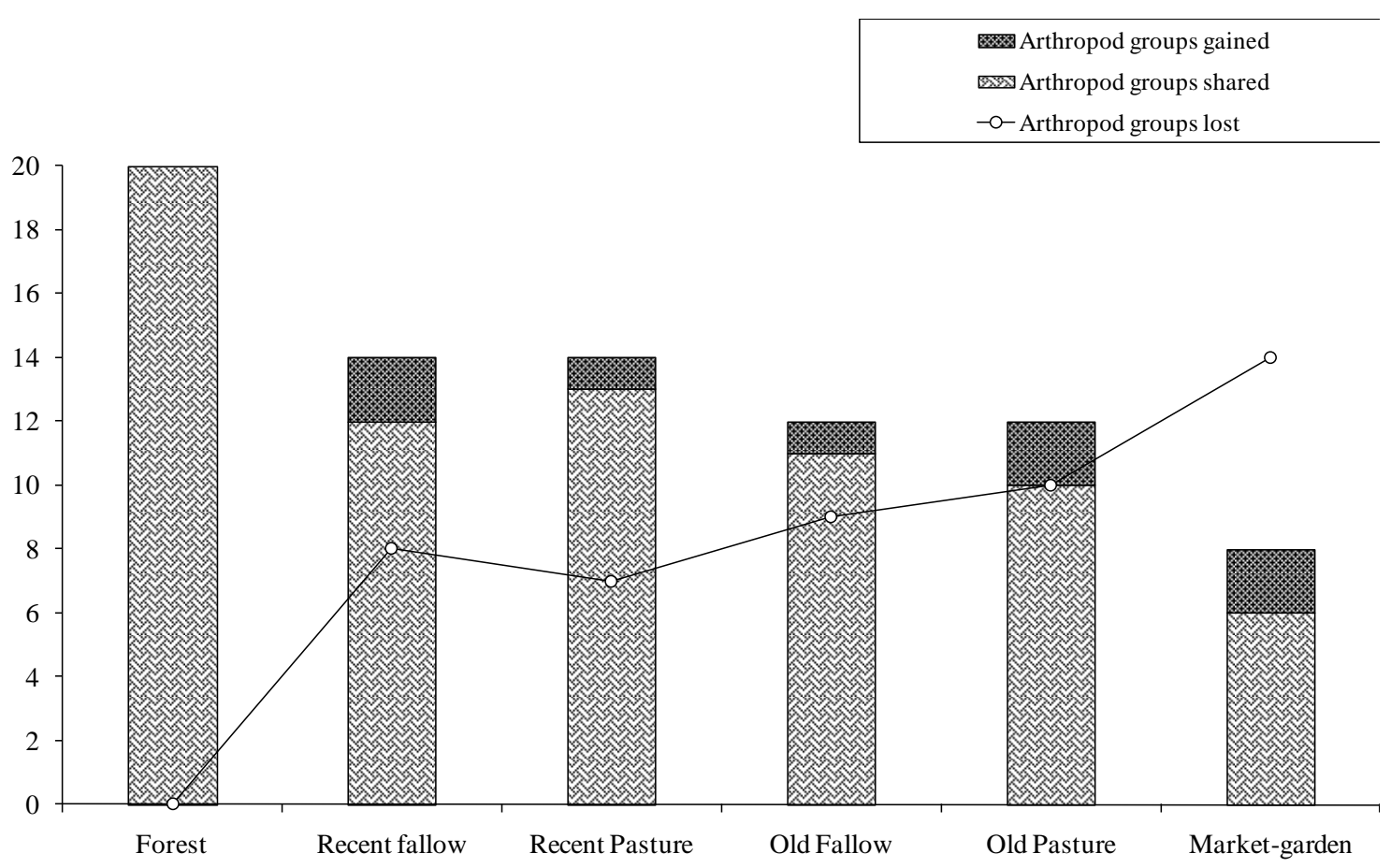

Fig. 2 


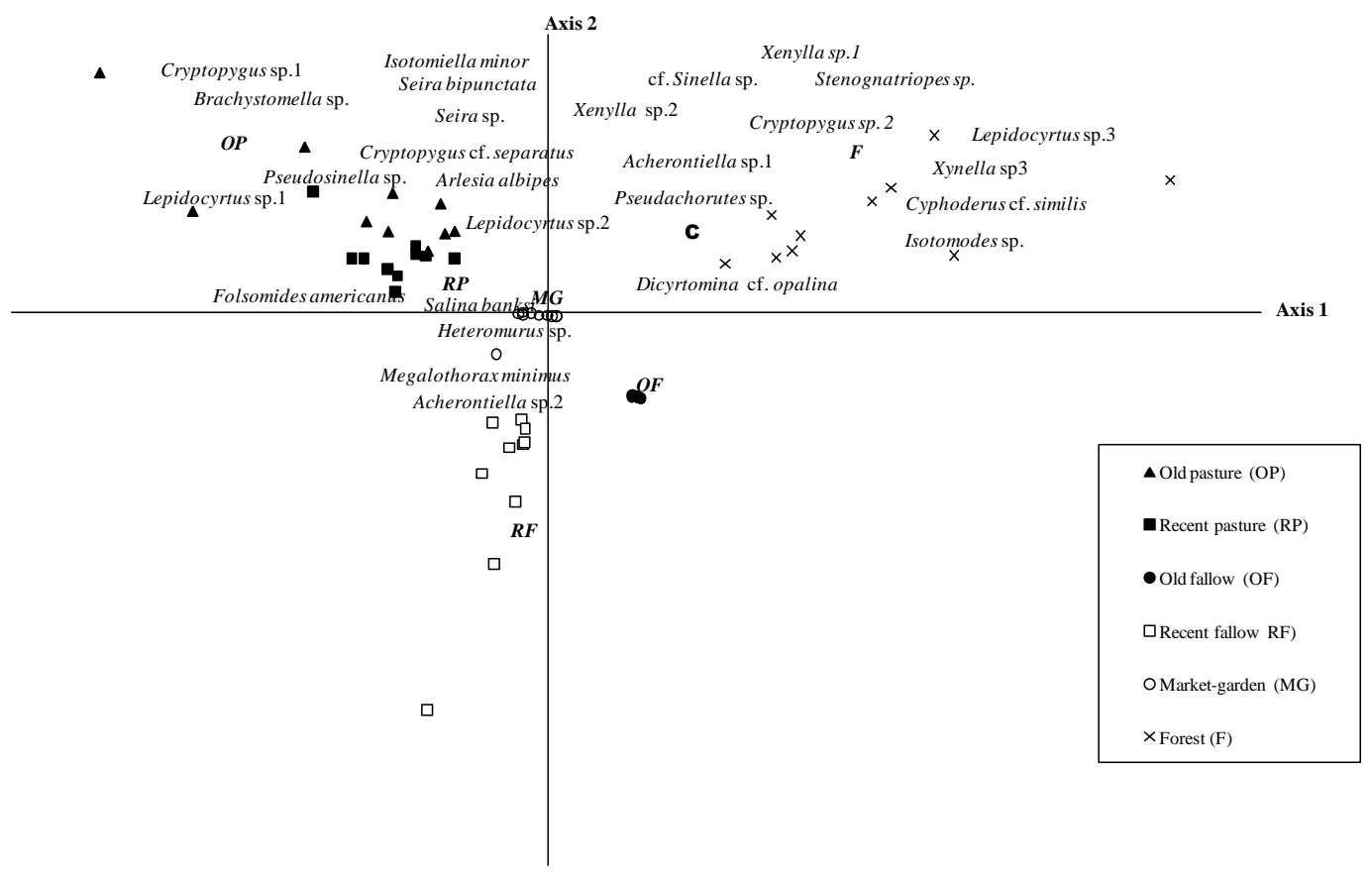

Fig. 3 


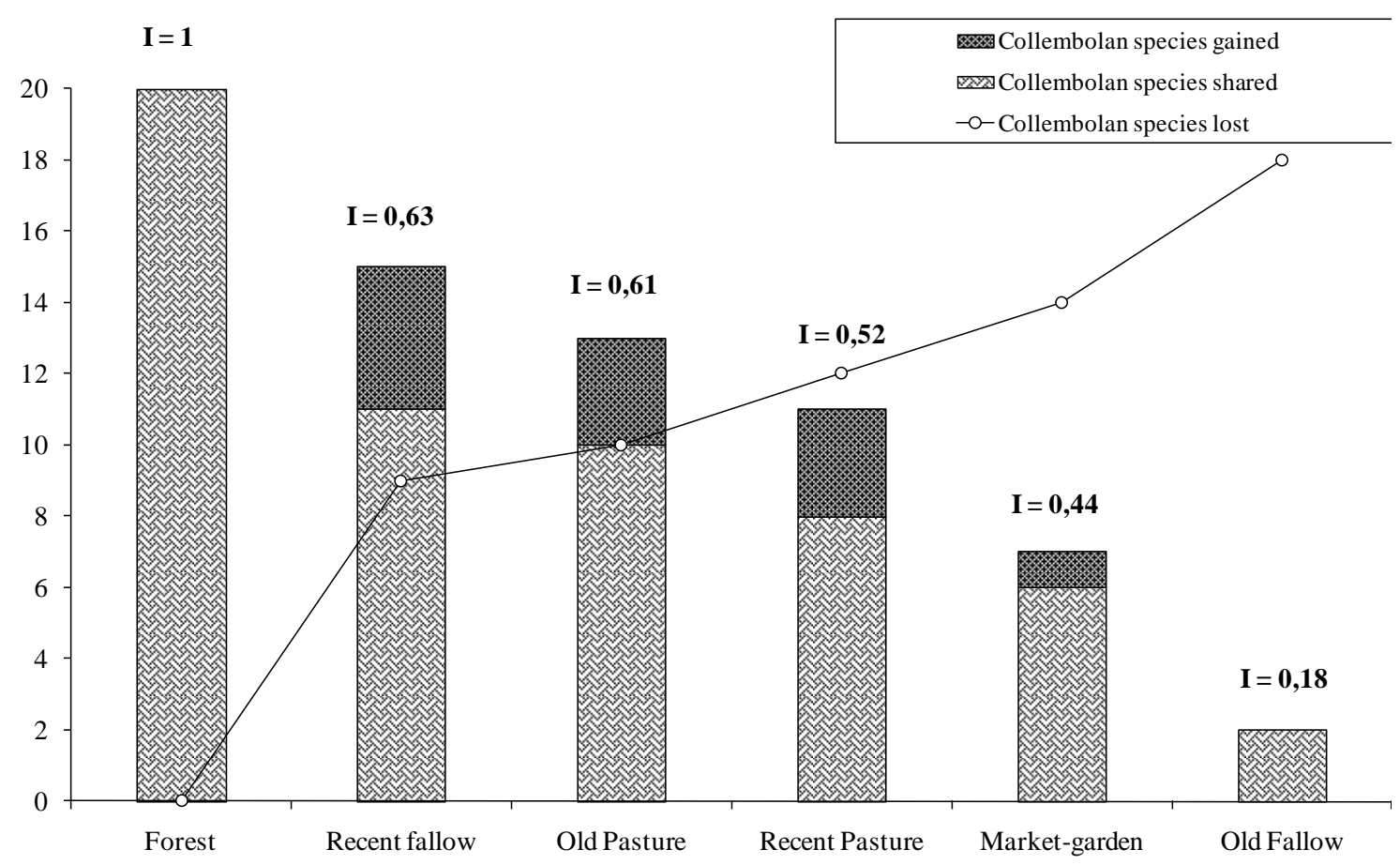

Fig. 4 